\title{
STRATEGI PENGEMBANGAN WISATA SYARIAH DI PROVINSI JAWA BARAT
}

\author{
Misno \\ Program Studi Muamalah Sekolah Tinggi Ekonomi Islam Tazkia \\ Jl. Ir. H. Djuanda Nomor 78 Sentul City Bogor \\ Email: drmisnomei@tazkia.ac.id
}

\begin{abstract}
Abstrak
Wisata Syariah adalah istilah yang digunakan oleh Kementerian Pariwisata dan Ekonomi Kreatif Republik Indonesia untuk program wisata yang berbasis pada nilai-nilai Syariah Islam. Jawa Barat sebagai salah satu destinasi wisata syariah yang memiliki potensi objek wisata yang bisa dikembangkan sesuai nilai-nilai syariah Islam, yaitu Kampung Dukuh dan Kampung Naga. Tujuan penelitian ini untuk mengidentifikasi potensi wisata syariah di Kampung Dukuh dan Kampung Naga, menganalisis lingkungan internal dan eksternal dan menentukan strategi pengembangan kedua kampung adat sebagai daya tarik wisata syariah. Data dalam penelitian ini diperoleh melalui metode observasi partisipatif, wawancara dan dokumentasi. Hasil penelitian menunjukan kekuatan wisata syariah di Kampung Dukuh dan Kampung Naga meliputi nilai dan ritual keagamaan masyarakat, objek wisata ziarah, arsitektur unik, keindahan alam pegunungan, akses jalan bagus (Kampung Naga). Sedangkan kelemahan Kampung Dukuh dan Kampung Naga meliputi kurang ketersediaan transportasi (Kampung Dukuh), kurangnya sarana pariwisata, kurang tersedianya lahan parkir (Kampung Dukuh), minimnya fasilitas toilet, belum maksimalnya promosi, belum tersedianya Tourist Information Center (Kampung Dukuh). Berdasarkan analisis kekuatan dan kelemahan dirumuskan empat strategi pengembangan yang bisa diterapkan, yaitu strategi pengembangan produk, strategi pengembangan promosi, strategi pariwisata berkelanjutan dan strategi pengembangan Sumber Daya Manusia (SDM) berbasis nilai-nilai Syariat Islam.
\end{abstract}

\section{Kata kunci:}

Kampung Dukuh, Kampung Naga, Strategi Wisata Syariah 


\section{A. Pendahuluan}

Undang-Undang Nomor 10 Tahun 2009 tentang Kepariwisataan pasal 5 butir (a) menyebutkan, "Kepariwisataan diselenggarakan dengan prinsip menjunjung tinggi norma agama dan nilai budaya sebagai pengejawantahan dari konsep hidup dalam keseimbangan hubungan antara manusia dan Tuhan Yang Maha Esa, hubungan antara manusia dan sesama manusia, dan hubungan antara manusia dan lingkungan". Berdasarkan pasal ini maka kebijakan pengembangan pariwisata di Indonesia harus didasarkan pada nilai-nilai agama dan adat-istiadat di suatu wilayah yang ditetapkan sebagai destinasi wisata. Indonesia sebagai negara dengan penduduk mayoritas beragama Islam (http://bps.go.id) memiliki kekayaan tradisi dan adat-istiadat yang tidak bisa dipisahkan dari agamanya.Sehingga tradisi dan budaya yang ada di masyarakat saat ini adalah manifestasi dari agama dan kepercayaannya. Berangkat dari fenomena inilah maka objek wisata dalam bentuk budaya di Indonesia pada umumnya adalah bagian dari agama Islam yang telah menjadi kebanggaan masyarakat Indonesia. Sehingga apabila budaya tersebut akan dijadikan objek wisata maka mau tidak mau harus mempertimbangkan agama masyarakatnya.

Kekayaan tradisi, budaya, agama dan adat-istiadat masyarakat muslimIndonesia inilah yang melatarbelakangi munculnya Program Wisata Syariaholeh pemerintah Republik Indonesia melalui Kementerian Pariwisata dan Ekonomi Kreatif (Kemenparekraf) (http://www.budpar.go.id). Alasan utama dikembangkannya program ini adalah karena meningkatnya minat masyarakat lokal dan internasional terhadap layanan wisata berbasis syariah Islam. Kemenparekraf mencatat bahwa kunjungan wisatawan muslim ke Indonesia saat ini mencapai 1.270.437 orang per tahun yang antara lain berasal dari Arab Saudi, Bahrain, Malaysia, dan Singapura. Seperti juga negara-negara lain di dunia, produk dan pelayanan wisata dengan nilai-nilai syariah ini diminati oleh wisatawan muslim yang populasinya mencapai 1,8 milyar atau $28 \%$ total populasi dunia.

Wisatawan muslim berkontribusi sekitar US \$126 miliar pada tahun 2011, dan diperkirakan pada tahun 2020 mereka akan membelanjakan US\$192 miliar untuk kebutuhan wisata mereka. Jumlah ini merupakan 13,4\% dari pengeluaran wisatawan global, dan akan terus meningkat pada tahun-tahuun berikutnya. Pada delapan tahun ke depan diproyeksikan pertumbuhannya mencapai $4,8 \%$ per tahun, 
sementara wisman global diproyeksikan pertumbuhannya 3,8\%. Saat ini $50 \%$ dari penduduk muslim di dunia berjumlah 1,8 miliar dan berada di usia kurang dari 25 tahun. Ini berarti mereka berada pada usia produktif dan memiliki potensi besar untuk bepergian menjadi wisman. ${ }^{1}$

Berdasarkan fakta tersebut maka Kementerian Pariwisata dan Ekonomi Kreatif telah menetapkan sedikitnya sembilan destinasi wisata yang saat ini mempunyai potensi untuk dipromosikan sebagai destinasi Wisata Syariah yaitu Sumatera Barat, Riau, Lampung, Banten, Jakarta, Jawa Barat, Jawa Timur, Makasar, Lombok. Jawa Barat adalah salah satu dari provinsi yang menjadi destinasi Wisata Syariah di Indonesia.Hal ini didasarkan pada kenyataan bahwa masyarakat di Jawa Barat mayoritas beragama Islam dan memiliki kekayaan budaya yang bisa dijadikan objek wisata unggulan. Potensi wisata di Jawa Barat dapat dilihat pada tabel berikut:

\section{Tabel 1}

\section{Data Potensi Objek dan Daya Tarik Wisata di Jawa Barat}

DATA POTENSI OBJEK DAN DAYA TARIK WISATA DI PROVINSI JAWA BARAT TAHUN 2011

\begin{tabular}{|c|c|c|c|c|c|c|c|c|c|}
\hline \multirow{3}{*}{ No. } & \multirow{3}{*}{ KABUPATENMOTA } & \multicolumn{3}{|c|}{ JENIS OBJEK WISATA } & \multirow{3}{*}{$\begin{array}{l}\text { JUIILAH } \\
\text { OBJEK } \\
\text { WISATA }\end{array}$} & \multirow{3}{*}{ LUAS (Ha) } & \multirow{2}{*}{\multicolumn{2}{|c|}{$\begin{array}{c}\text { JUILAH } \\
\text { TENAGA KERJA }\end{array}$}} & \multirow{3}{*}{$\begin{array}{c}\text { TOTAL } \\
\text { TENAGA } \\
\text { KERJA }\end{array}$} \\
\hline & & \multirow{2}{*}{ ALAM } & \multirow{2}{*}{ BUDAYA } & \multirow{2}{*}{$\begin{array}{l}\text { MINIAT } \\
\text { KHUSUS }\end{array}$} & & & & & \\
\hline & & & & & & & PRIA & WANITA & \\
\hline 1 & 2 & 3 & 4 & 5 & 6 & 7 & 8 & 9 & 10 \\
\hline 1. & Kabupaten Bogor & 38 & 3 & 4 & 45 & $28,650.0$ & 1,456 & 671 & 2,127 \\
\hline 2. & Kabupaten Sukabumi & 36 & 7 & 7 & 50 & $32,520.0$ & 120 & 81 & 201 \\
\hline 3 & Kabupaten Cianjur & 12 & 4 & 1 & 17 & 4.955 .1 & 306 & 124 & 430 \\
\hline 4 & Kabupaten Bandung & 39 & 14 & 2 & 55 & 1,0885 & 89 & 33 & 122 \\
\hline 5 & Kabupaten Garut & 24 & 3 & 1 & 28 & 1.1299 & 453 & 33 & 486 \\
\hline 6. & Kabupaten Tasikmalaya & 10 & 2 & 1 & 13 & 469.0 & 71 & 1 & 72 \\
\hline 7 & Kabupaten Ciamis & 16 & 0 & 7 & 23 & 1.1395 & 62 & 3 & 65 \\
\hline 8 & Kabupaten Kuningan & 19 & $\frac{6}{6}$ & 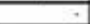 & 25 & 300.3 & 181 & 40 & 221 \\
\hline 9. & Kabupaten Cirabon & 6 & 4 & - & 10 & 79.7 & 66 & . & 66 \\
\hline 10. & Kabupaten Majalengka & 7 & - & 2 & 9 & 128.0 & 112 & 17 & 129 \\
\hline 11. & Kabupaten Sumedang & 12 & 7 & 7 & 26 & 242.3 & 320 & 72 & 392 \\
\hline 12. & Kabupaten Indramayu & 4 & 1 & - & 5 & 213.1 & 14 & 3 & 17 \\
\hline 13 & Kabupaten Subang & 33 & 5 & & 38 & 2.9345 & 740 & 134 & 874 \\
\hline 14. & Kabupaten Purwakarta & 16 & 12 & 23 & 51 & $37,307.5$ & 61 & 18 & 79 \\
\hline 15. & Kabupaten Karawang & 12 & 9 & 3 & 24 & 428.0 & 137 & 26 & 163 \\
\hline 16. & Kabupaten Bekasi ${ }^{*}$ & 4 & 3 & 3 & 10 & $1,423.0$ & 6 & 4 & 10 \\
\hline 17. & Kabupaten Bandung Barat. & 25 & 10 & 3 & 38 & 47729 & 350 & 117 & 467 \\
\hline 18. & Kota Bogor ${ }^{*}$ & & - & 16 & 16 & 14.557 .0 & 677 & 501 & 1,178 \\
\hline 19. & Kota Sukabumi & 2 & - & - & 2 & 10.3 & 9 & 1 & 10 \\
\hline 20. & Kota Bandung & 3 & 2 & 6 & 11 & 21.6 & 392 & 149 & 541 \\
\hline 21. & Kota Cirebon ${ }^{*}$ & 1 & 8 & 1 & 10 & 47.3 & 106 & 12 & 118 \\
\hline 22 & Kota Bokas " & - &. &. &. & - & - &. &. \\
\hline 23. & Kota Depok* & 6 & - & - & 6 & 10.0 & 1,091 & 17 & 1,108 \\
\hline 24. & Kota Cimahi & 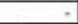 & 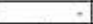 & 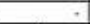 & 0 & 0.0 & 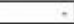 & 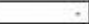 & 0 \\
\hline 25. & Kota Tasikmalaya & 1 & 1 & 2 & 4 & 77.4 & - & - & 117 \\
\hline 26. & Kota Banjar & 1 & - & - & 1 & 3.5 & 2 & 1 & 3 \\
\hline & JUILAH & 327 & 101 & 89 & 517 & $132,508.5$ & 6,821 & 2,058 & $\overline{8,996}$ \\
\hline
\end{tabular}

Tabel ini menunjukan bahwa potensi wisata Jawa Barat didominasi oleh Kabupaten Bandung, Kabupaten Bogor dan Kabupaten Sukabumi.Sementara potensi wisata budaya didominasi oleh Kabupaten

${ }^{1}$ Newsletter, "Pariwisata Indonesia”, Edisi 37 Januari 2013. 
Bandung, Kabupaten Purwakarta dan Kabupaten Bandung Barat. Pada tabel "Destinasi Khusus" Kabupaten Purwakarta mendominasi, kemudian Kota Bogor dan Kabupaten Sukabumi, serta Kabupaten Sumedang dan Kabupaten Ciamis (http://www.budpar.go.id.).Tabel ini juga menunjukan bahwa potensi wisata di Kabupaten Tasikmalaya dan Garut berada pada peringkat bawah padahal kedua kabupaten ini memiliki objek wisata sejarah dan budaya langka seperti Kampung Dukuh dan Kampung Naga yang bisa dikembangkan menjadi destinasi Wisata Syariah.

Kampung Dukuh dan Kampung Naga adalah dua di antara kampung adat yang menjadi destinasi wisata budaya di Jawa Barat. Kedua kampung ini memiliki keunikan tersendiri karena masyarakatnya masih melaksanakan adat-istiadat secara ketat yang mereka warisi dari nenek moyang mereka.Seluruh masyarakat Kampung Dukuh dan Kampung Naga beragama Islam sehingga adat-istiadat mereka terkait erat dengan ritual dan kepercayaan Islam. ${ }^{2}$ Daya tarik wisata di Kampung Dukuh dan Kampung Naga adalah tradisi, budaya dan agama yang saat ini masih dilestarikan oleh masyarakatnya.Beberapa objek yang menarik bagi para wisatawan adalah arsitektur rumah tradisional, pola pemukiman, ritual keagamaan dan budaya karuhun yang hingga saat ini masih dilaksanakan pada waktu-waktu tertentu.Berdasarkan keunikan tersebut maka Kampung Dukuh dan Kampung Naga telah ditetapkan oleh Dinas Pariwisata Provinsi Jawa Barat sebagai destinasi wisata budaya di Jawa Barat, selain kampung adat lainnya yaitu: Kampung Kuta di Ciamis, Kampung Pulo di Garut, Kampung Mahmud di Bandung, Kampung Urug di Bogor, Kampung Banceu di Subang, Kampung Cigugur di Kuningan dan beberapa kampung adat lainnya.

Penelitian ini akan merumuskan strategi pengembangan potensi wisata berbasis syariah di Kampung Dukuh dan Kampung Naga. Tujuannya adalah untuk mengidentifikasi potensi wisata syariah pada Kampung Dukuh dan Kampung Naga, menganalisis lingkungan internal dan eksternal dan menentukan strategi pengembangan kedua kampung adat sebagai daya tarik wisata syariah. Data dalam penelitian ini diperoleh melalui metode observasi partisipatif, wawancara mendalam dan dokumentasi.Penelitian ini bersifat eksploratif, merumuskan program-program berdasarkan kondisi internal dan kondisi eksternal di

2 Wawancara dengan Ketua Adat Kampung Dukuh Mama Uluk dan Kuncen Kampung Naga Bpk. Ade Suherlin. 
kedua lokasi penelitian.Analisis yang digunakan adalah analisis Strength, Weaknesses, Opportunities dan Threats (SWOT) untuk melihat peluang dan tantangan pengembangan wisata syariah di kedua lokasi penelitian.

\section{B. Kondisi Geografis Kampung Dukuh dan Kampung Naga}

Secara administrasi Kampung Dukuh termasuk ke dalam wilayah Desa Ciroyom, pemekaran dari Desa Cijambe, Kecamatan Cikelet, Kabupaten Garut Provinsi Jawa Barat.Kampung Dukuh masuk ke dalam wilayah RT. 01, 02, 03 RW.06 Kedusunan Barujaya. Secara geografis kampung ini berada pada ketinggian $390 \mathrm{~m}$ di atas permukaan laut, dengan suhu rata-rata 26 derajat C. Sedangkan letak astronomisnya terletak pada garis 7 - 8 derajat LS dan 7 - 108 derajat BT. Jarak tempuh dari ibu kota Provinsi Jawa Barat sekitar 167 KM. sementara jarak dari ibu kota Kabupaten Garut sekitar 102 KM dan jarak dari ibu kota Kecamatan sekitar $6 \mathrm{KM}$.

Luas pusat Kampung Dukuh kurang lebih 1,5 Ha. Dengan tipe pemukiman berkelompok terdiri dari beberapa rumah yang tersusun pada kemiringan rumah yang bertingkat dari tingkatan dan dari tingkatan terdapat sederetan rumah yang membujur dari Barat ke Timur. Wilayah Kampung Dukuh terbagi dalam dua wilayah Dukuh Leubet (dalam), Dukuh luar, dan tanah karomah (makam Syeikh Abdul Djalil dan para pengikutnya).Begitu juga ada tanah yang difungsikan untuk tanah cadangan pemukiman, yaitu taneh awisan (Taneh Awisan yaitu tanah yang menjadi warisan dari Kerajaan Sumedang sebagai tempat mendirikan rumah bagi masyarakat (Kampung Dukuh) Sumedang, Sukapura, dan Arab.

Secara keseluruhan luas wilayah adat Dukuh kurang lebih 4.684,23 Ha. Sekitar 4.559,48 (97,3\%) merupakan lahan pertanian, perkebunan, dan hutan. Sedangkan sisanya kurang lebih 124,75 Ha. $(2,7 \%)$ merupakan wilayah yang digunakan sebagai pemukiman penduduk, sarana pedesaan, sekolah, perkantoran, tempat olahraga, pemakaman, tempat peribadatan dan lahan tandus.

Sementara Kampung Naga secara administratif berada di wilayah RT 01 RW 01 Desa Neglasari Kecamatan Salawu Kabupaten Tasikmalaya Provinsi Jawa Barat. Luas keseluruhan wilayahnya adalah $10 \mathrm{Ha}$, yang terdiri dari kawasan hutan lindung dan hutan larangan seluas 3,5 Ha, lahan untuk pemukiman seluas $\pm 1,5$ Ha dan untuk kebun serta 
pertanian \pm 5 Ha. $^{3}$ Posisi Kampung Naga berdasarkan pengukuran GPS

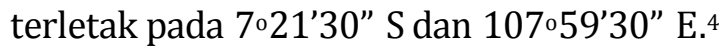

Kondisi geografis wilayahnya berupa lembah yang dikelilingi oleh perbukitan, permukaan tanah di bagian barat merupakan kondisi tanah yang memiliki kontur lebih tinggi dibandingkan dengan permukaan tanah di bagian timur. Masyarakat Sunda menyebut kondisi permukaan tanah seperti dengan istilah taneuh behe ngetan (kondisi permukaan tanah yang memiliki kontur lebih miring ke arah timur).Berdasarkan kepercayaan, sebuah daerah yang memiliki kemiringan tanah seperti itu merupakan tempat ideal, baik untuk lahan pemukiman maupun pertanian. Secara rasional, kepercayaan semacam itu dapat dipahami, karena daerah yang memiliki kemiringan tanah ke arah timur akan memperoleh sinar matahari pagi yang lebih banyak. Hal demikian memungkinkan penghuninya lebih sehat karena pengaruh sinar ultraviolet di pagi hari yang memadai. ${ }^{5}$

\section{Potensi Wisata Syariah di Kampung Dukuh dan Kampung Naga}

\section{Potensi Wisata Kampung Dukuh}

Kampung Dukuh adalah kampung adat yang kaya dengan potensi wisata berbasis syariah yang bisa dikembangkan sebagai destinasi bagi wisatawan domestik dan mancanegara. Arsitektur rumah, bale dan masjid menjadi core destinasi wisata di Kampung Dukuh yang sangat menarik bagi para wisatawan yang ingin mengetahui lebih jauh mengenai arsitektur Sunda Kuno. Selain itu pola pemukiman dan peruntukan lahan juga menarik untuk dijadikan andalan wisata Kampung Dukuh. Selanjutnya makam Syaikh Abdul Jalil yang dijadikan tempat bagi para peziarah untuk bertawasul, berdoa dan memohon karomah adalah destinasi wisata religius yang belum dikembangkan secara maksimal. Hingga penelitian ini selesai para pengunjung yang datang ke Kampung Dukuh diterima langsung oleh kuncen dan menginap di bale khusus yang disediakan untuk pada tamu (peziarah).

\footnotetext{
${ }^{3}$ Ismet Belgawan Harun dkk, Arsitektur Rumah dan Permukiman Tradisional di Jawa Barat.Hasil Pengamatan dan Dokumentasi (Bandung: Dinas Pariwisata dan Kebudayaan Provinsi Jawa Barat. 2011). hlm. 89.

${ }^{4}$ Ibid., hlm. 32.

${ }^{5}$ Her Suganda, Kampung Naga Mempertahankan Tradisi (Bandung: PT. Kiblat Buku Utama. 2005), hlm. 19.
} 
Kesenian, Tradisi dan budaya masyarakat Kampung Dukuh sangat beragam dan exotic.Kesenian yang saat ini ada misalnya seni terbang seja', barjanji, addeba', manakiban, tutunggulan (Tabuhan Lisung/tempat menumbuk padi) dengan menggunakan halu (alat untuk menumbuk padi) dilakukan oleh tiga orang atau lebih. Terbang disebut juga kempring atau gembring adalah sejenis rebana yang berukuran besar. Satu grup terbang seja' terdiri atas empat buah terbang, dipukul dengan irama monoton mengikuti nyanyian yang berisi puji-pujian kepada Allah Subhanahu wata'ala atas kebesaran-Nya atau puji-pujian terhadap kemuliaan Nabi Muhammad Shalallahu'alaihi wa sallam. Sebagai selingan, dipertunjukan aktraksi yang memperlihatkan berbagai ilmu kedigjayaan (kesaktian) seperti halnya debus dari Banten, tetapi dengan pelaksanaan yang lebih sederhana diantaranya menyayatkan golok ke seluruh tubuh (ngesrek), Mamacanan, memikul tongkat (halu; kayu yang biasa digunakan untuk menumbuk padi) dengan enam orang atau lebih yang ditengahnya terdapat ikatan saputangan, sampai jatuh tudak kuasa memikil tongkat tersebut sulap, memanjat kelapa memiliki kecepatan sama dengan macan dan lain-lain. ${ }^{6}$

Barjanji dan atau addeba', adalah membaca sejarah riwayat kepada Nabi Muhammad Shalallahu'alaihi wa sallam sejak dilahirkan sampai wafatnya. Riwayat nabi tersebut ditulis dalam sebuah buku dalam bentuk bait sya'ir seperti pupuh dan dibawakan sesuai dengan sya'irnya, seperti bentuk sinom, kidung dan asmarandana. Pelaksanaan Ad-Debai' biasanya dilaksanakan setelah shalat maghrib atau kalau ada hubungannya dengan hajat masyarakat (tasyakuran) maka pelaksanaannya setelah shalat Isya, lamanya tergantung yang punya hajat atau persetujuan pembaca riwayat yang terdiri atas beberapa laki-laki, yaitu para sesepuh kampung termasuk kuncen dan habib.Manakiban adalah membaca shalawat Syekh Abdul Qodir Jaelani (penyebar agama Islam yang sangat terkenal). Biasanya dilakukan pada bulan mulud dan waktu-waktu yang telah ditentukan oleh tetua adat. ${ }^{7}$

Selain adanya kesenian tersebut, beberapa tradisi masih dipertahankan hingga saat ini di Kampung Dukuh.Diantaranya adalah Upacara Moros, yaitu salah satu manisfestasi masyarakat Kampung Dukuh dengan memberikan hasil pertanian kepada pemerintah menjelang Idul Fitri dan Idul Adha.Selain itu, ada juga ritual Ngahaturan

\footnotetext{
${ }^{6}$ Wawancara dengan Kang Yayan warga Kampung Dukuh.

7 Wawancara dengan Kang Sholaha warga Kampung Dukuh.
} 
Tuang. Kegiatan ini dilakukan masyarakat Kampung Dukuh atau pengunjung yang berasal dari luar apabila mereka memiliki keinginankeinginan tertentu seperti kelancaran usaha, perkawinan, jodoh, dengan cara memberikan bahan makanan seperti garam, telur ayam, kelapa, kambing atau barang lainnya sesuai kemampuan. Selanjutnya adalah tradisi Nyangggakeun, yaitu kegiatan penyerahan sebagian hasil pertanian kepada kuncen untuk diberkahi.Menurut keyakinan mereka padi tidak boleh dimakan sebelum dilakukan kegiatan nyanggakeun.

Ada juga upacara Tilu Waktos, ritual ini hanya dilakukan oleh Kuncen yaitu membawa makanan ke dalam Bumi Alit atau bumi Leubet untuk tawasul.Kuncen membawa sebagian makanan ke Bumi Alit lalu berdoa, dilakukan pada hari raya 1 Syawal, 10 Rayagung, 12 Maulid, dan 10 Muharam. Kemudian terdapat pula ritual Manuja, yaitu penyerahan bahan makanan dari hasil bumi kepada Kuncen untuk diberkahi pada hari raya Idul Fitri dan Idul Adha untuk selanjutnya dijadikan bahan untuk perayaan Maresyaitu menyerahkan hasil bumi yang dimiliki kepada aparat pemerintah seperti Lurah dan Camat.

Selain itu dikenal pula upacara Cebor Opat Puluh, yaitu mandi dengan empat puluh kali siraman dengan air dari pancuran dan dicampur dengan air khusus yang telah diberi doa-doa pada tempat mandi umum.Lalu upacara Jaroh yang merupakan suatu aktivitas keagamaan yang berbentuk ziarah ke makam Syekh Abdul Jalil tetapi sebelumnya harus melakukan mandi cebor opat puluh dan mengambil air wudhu serta menanggalkan semua perhiasan dan menggunakan pakaian yang tidak bercorak. ${ }^{8}$

Upacara Shalawatan dilakukan pada hari Jumat di rumah Kuncen. Shalawatan dilaksanakan sebanyak 4444 yang dihitung dengan menggunakan batu Sebelasan.Dilakukan setiap tanggal 11 dalam perhitungan bulan Islam dengan membaca Marekah Terbang Gembrung. Kegiatan terbang gembrung ini dilakukan pada tanggal 12 Maulud yang dilakukan para orang tua Kampung Dukuh.Selain itu, terdapat beberapa hari besar di Kampung Dukuh seperti 1 Syawal, 10 Rayagung, 12 Maulid, dan 10 Muharam.Sedangkan hari-hari penting diantaranya, Sabtu (pelaksanaan ziarah), Rebo Wekasan (hari terakhir bulan Sapar dimana semua sumber air, yang digunakan masyarakat diberi jimat sebagai penolak bala, dan biasanya diwajibkan mandi), dan 14 Maulud.Tanggal

\footnotetext{
${ }^{8}$ Wawancara dengan Ketua Adat Kampung Dukuh Mama Uluk.
} 
ini dipercaya sebagai hari baik untuk menguji dan mencari ilmu kepada guru dengan melakukan cebor opat puluh.

Beberapa potensi tersebut saat ini belum dikembangkan sebagai objek wisata syariah, sehingga pengunjung ke kampung ini masih terbatas untuk berziarah dan mencari barokah dari ketua adat dan Makam Syaikh Abdul Jalil saja.Padahal jika dikembangkan maka tradisitradisi tersebut menjadi objek wisata syariah yang banyak diminati oleh para wisatawan.

\section{Potensi Wisata Kampung Naga}

Saat ini Kampung Naga telah menjadi objek wisata unggulan bagi Kabupaten Tasikmalaya dan Jawa Barat.Kampung Naga ditetapkan sebagai objek wisata dengan Peraturan Daerah Nomor 2 Tahun 2005 tentang Rencana Tata Ruang Wilayah Kabupaten Tasikmalaya. Para pengunjung tidak hanya berasal dari dalam negeri tapi juga banyak wisatawan manca negara. Potensi utama dari Kampung Naga adalah arsitektur rumah dan pola pemukimannya.Rumah di Kampung Naga menggunakan bahan-bahan alami berupa kayu dan bambu. Atap rumahnya menggunakan injuk dan daun tepus sehingga memiliki kekhasan tersendiri. Rumah-rumah di Kampung Naga berbanjar menghadap utara dan selatan dengan posisi berhadap-hadapan. Pola peruntukan wilayah didasarkan pada mitologi tritangtu yaitu kawasan suci berupa makam keramat, kawasan bersih untuk perumahan warga dan kawasan kotor untuk kandang ternak, kolam ikan, saung lisung dan MCK. ${ }^{9}$

Tradisi yang ada di Kampung Naga sangat banyak sekali terdiri dari kesenian, perayaan, ritual dan ziarah. Kesenian di Kampung Naga yaitu Terbang Gembrung dan Terbang Sejak. Terbang Gembrung adalah sejenis rebana dalam bentuk yang lebih besar, ia hanya dimainkan untuk mengiringi takbir dan shalawat pada saat malam hari hari raya Idhul Fitri, Idhul Adha dan Muludan. Alat musik ini tidak boleh dimainkan pada selain momen-momen tersebut. Sedangkan Terbang Sejak adalah rebana dengan ukuran yang lebih kecil dan bisa dimainkan kapan saja dan di mana saja serta untuk mengiringi berbagai shalawat, lagu-lagu religious dan lagu popular lainnya. Penulis mendapatkan kesempatan untuk menyaksikan langsung kegiatan menabuh terbang gembrung pada acara takbiran dan muludan pada tahun 2012 .

\footnotetext{
${ }^{9}$ Wawancara dengan Kuncen Kampung Naga Bpk. Ade Suherlin.
} 
Tradisi Kampung Naga dalam bentuk ritual adalah perayaan Hajat Sasih setiap dua bulan sekali. Inti dari ritual ini adalah ziarah ke makam leluhur lembur yaitu Sembah Dalem Eyang Singaparana dengan sebelumnya mandi dan abdas di sungai Ciwulan. Acara ini diakhiri dengan ngariung dan makan bersama di masjid.Warga Kampung Naga yang perempuan membawa tumpeng untuk didoakan di masjid dan setelah itu dibawa pulang ke rumah untuk dimakan bersama dengan anggota keluarga lainnya. Pelaksanaan perayaan ini telah ditetapkan waktunya sejak dahulu yaitu pada:

a. Bulan Muharam (Muharram) pada tanggal 1, 2 atau 3;

b. Bulan Maulud (Rabiul Awal) pada tanggal 12, 13, atau 14;

c. Bulan Jumadil Akhir pada tanggal 14, 15, atau 16;

d. Bulan Rewah (Sya'ban) pada tanggal 26, 27, atau 28;

e. Bulan Syawal (Syawal) pada tanggal 1, 2, atau 3; dan

f. Bulan Rayagung (Dzulkaidah) pada tanggal 10, 11 atau 12.10

Selain itu terdapat pula acara ngaruwat lembur pada bulan Muharam yang berupa permohonan kepada Tuhan agar seluruh masyarakat diberikan kehidupan yang baik pada tahun yang akan datang. Pada acara ini dilaksanakan pemotongan kambing dan ayam sebagai symbol pengorbanan dari masyarakat Kampung Naga kepada Sang Pencipta.Pada bulan mulud selain dilaksanakan Hajat Sasih juga dilakukan acara mapag sasih mulud yaitu menyambut bulan Maulud dan mileuleuyenken sasih mulud melepas bulan Maulud.Masih pada bulan mulud dilakukan pula ngawilah yaitu mengganti kandang jaga secara bersama-sama seluruh masyarakat Kampung Naga.

Berdasarkan pengamatan di lapangan, hanya perayaan hajat sasih di Kampung Naga yang dijadikan objek wisata dan diekspos ke masyarakat, padahal kalau dioptimalkan setiap kegiatan ritual dan momen yang ada maka bisa menjadi objek wisata syariah yang menarik bagi wisatawan baik domestik maupun mancanegara.

\section{Analisis Potensi Wisata Syariah di Kampung Dukuh dan Kampung Naga}

Berdasarkan pemaparan mengenai tradisi dan budaya di Kampung Dukuh dan Kampung Naga sebelumnya, tergambarkan bahwa kedua kampung ini memiliki kekayaan tradisi dan budaya yang sangat 
banyak dan potensial menjadi objek wisata syariah. Namun sangat disayangkan bahwa potensi tersebut belum digali dan belum dijadikan wisata unggulan untuk menarik para wisatawan lebih banyak berkunjung ke dua lokasi wisata tersebut. Oleh karena itu dibutuhkan sebuah strategi bagi pengembangan wisata syariah karena potensi yang besar tersebut tidak akan bisa dimanfaatkan tanpa adanya strategi pengembangan.

Di dalam Kamus Besar Bahasa Indonesia disebutkan bahwa strategi adalah rencana yang cermat mengenai kegiatan untuk mencapai sasaran khusus. ${ }^{11}$ Sementara menurut Amirullah, strategi adalah suatu rencana dasar yang luas dari suatu tindakan organisasi untuk mencapai suatu tujuan. ${ }^{12}$ Rencana dalam mencapai tujuan tersebut sesuai dengan lingkungan eksternal dan internal perusahaan. Pada lingkungan perusahaan strategi merupakan alat untuk mencapai tujuan perusahaan dalam kaitannya dengan tujuan jangka panjang, program tindak lanjut serta prioritas alokasi sumber daya. ${ }^{13}$ Maka strategi adalah langkahlangkah yang dilakukan dengan mengoptimalkan sumber-sumber internal dan eksternal untuk mencapai tujuan tertentu.Kaitannya dengan pengembangan Wisata Syariah adalah bahwa strategi dilakukan untuk merancang suatu tindakan dengan mengoptimalkan potensi yang ada untuk kemajuan Wisata Syariah di Kampung Dukuh dan Kampung Naga. Sementara "pengembangan" adalah suatu proses, cara, dan perbuatan mengembangkan sesuatu menjadi lebih baik, maju sempurna dan berguna. ${ }^{14}$ Jadi strategi pengembangan wisata syariah adalah langkah-langkah yang dirumuskan untuk memelihara, memajukan dan menjadikan objek wisata syariah lebih menjadi menarik dan lebih berkembang sesuai dengan prinsip-prinsip syariah Islam.

Merujuk pada pendapat Butler yang dikutip oleh Cooper dan Jackson tentang Tourism Life Cycle dengan tahapan:15 Tahap exploration, Tahap involvement, Tahap development,Tahap consolidation dengan constitutionalism, Tahap stagnation yang masih diikuti institutionalism,

11 Poerwadarminton, Kamus Umum Bahasa Indonesia (Jakarta: Balai Pustaka. 2002), hlm. 159.

12 Amirullah, Manajemen Strategik (Yogyakarta: Graha Ilmu. 2004), hlm. 4.

13 Rangkuti, F. Analisis SWOT, Teknik Membedah Kasus Bisnis (Jakarta: PT. Gramedia Pustaka Utama. 2005), hlm. 3.

${ }^{14}$ Poerwadarminton, Kamus Umum Bahasa Indonesia. hlm. 538.

15 Cooper, C. And Jackson, S. L., Destination Life Cycle: The Isle of The man Case Study. (ed. Lesly, France) dalam The Earthscan Reader in Sustainable Tourism. (UK:: Earthscan Publication Limited. 1997), hlm. 34. 
dan Tahap decline, maka Kampung Dukuh dan Kampung Naga berada pada tahap awal yaitu tahap exploration dimana kedua lokasi mempunyai berbagai potensi daya tarik wisata lain yang masih tergolong baru dan pengunjung yang ada juga hanya sebatas masyarakat sekitarnya. Karena itu dukungan dari seluruh pihak terutama pemerintah, sesepuh adat, dan masyarakat sangat diharapkan bagi pengembangan wisata syariah pada dua lokasi ini.

Wisata syariah sebagai satu istilah baru didefinisikan sebagai kegiatan wisata yang didukung berbagai fasilitas dan layanan yang disediakan masyarakat, pengusaha, pemerintah yang memenuhi ketentuan syariah. ${ }^{16}$ Jika pada definisi ini makna "syariah" lebih pada pelayanan, maka produk dari wisata itu sendiri menjadi intinya. Sementara Islamic Tourisme Malaysia mendefinisikannya dengan any activity, event, experience or indulgence, undertaken in a state of travel that is in accorance with Islam. (http://www.itc.gov.my/content.cfm). Apabila dirumuskan maka ada empat standard sebuah wisata dikatakan bersyariah Pertama, persoalan halal food (makanan halal), kedua, arah kiblat, ketiga, penyediaan Kitab Suci Al-Quran dan keempat pembinaan syariah terhadap masyarakat di sekitar lokasi wisata.Selain itu setiap suguhan objek wisata tidak boleh bertentangan dengan nilai-nilai Islam, seperti pornografi, kemaksiatan, kesyirikan dan lain sebagainya.Sesuai dengan kriteria dari Wisata Syariah maka tradisi dan budaya serta objek wisata di Kampung Dukuh dan Kampung Naga sangat layak untuk dijadikan objek wisata syariah unggulan di Jawa Barat.

Sebelum menetapkan strategi pengembangan, maka terlebih dahulu dipaparkan kekuatan dan kelemahan masing-masing lokasi. Berikut adalah hasil analisisnya:

1. Analisis SWOT Wisata Syariah di Kampung Dukuh:

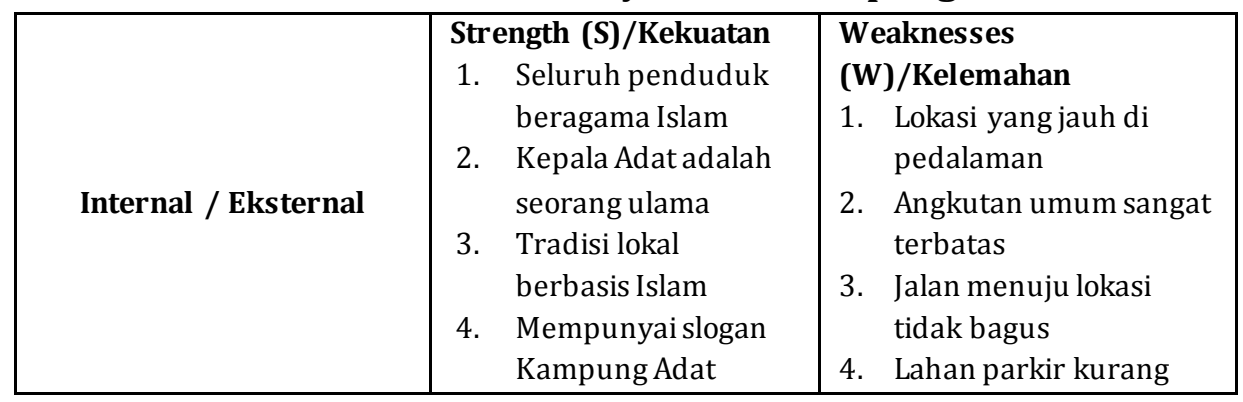

${ }^{16}$ Anonimous, Panduan Wisata Syariah (Jakarta: Kementerian Pariwisata dan Ekonomi Kreatif Republik Indonesia. 2014), hlm. 18. 


\begin{tabular}{|c|c|c|}
\hline & $\begin{array}{ll}\text { 5. } & \text { Islami } \\
& \text { Jakam Syaikh Abdul sebagai tempat } \\
& \text { ziarah } \\
\text { 6. } & \text { Kesenian lokal } \\
\text { berbasis Islam } \\
\text { 7. } & \text { Arsitektur rumah, } \\
\text { masjid dan pola } \\
\text { pemukiman yang } \\
\text { Islami } \\
\text { 8. Adat-istiadat Islami } \\
\text { 9. Keindahan } \\
\text { panorama alam }\end{array}$ & $\begin{array}{ll}\text { memadai } \\
\text { 5. } \\
\text { Kurangnya sarana } \\
\text { pariwisata } \\
\text { 6. } \\
\text { Tidak ada fasilitas toilet } \\
\text { untuk umum } \\
\text { 7. } \begin{array}{l}\text { Promosi belum } \\
\text { dilakukan dengan }\end{array} \\
\text { maksimal } \\
\text { 8. Tourist Information } \\
\text { Center (TIC) belum ada } \\
\text { 9. } \text { Belum ada pemandu } \\
\text { wisata yang bisa } \\
\text { menjelaskan keunikan } \\
\text { Kampung Dukuh }\end{array}$ \\
\hline $\begin{array}{l}\text { Opportunities } \\
\text { (0)/Peluang } \\
\text { 1. Kondisi ekonomi global } \\
\text { 2. Kondisi ekonomi } \\
\text { nasional } \\
\text { 3. Meningkatnya minat } \\
\text { masyarakat kota } \\
\text { terhadap kampung adat } \\
\text { 4. Peran serta masyarakat } \\
\text { dalam melestarikan } \\
\text { budaya Sunda } \\
\text { 5. Kondisi politik global } \\
\text { 6. Kondisi politik nasional } \\
\text { 7. Keamanan Kabupaten } \\
\text { Garut } \\
\text { 8. Kemajuan teknologi } \\
\text { informasi } \\
\text { 9. Kemampuan daya saing } \\
\text { dengan daya tarik } \\
\text { wisata sejenis }\end{array}$ & $\begin{array}{l}\text { Strategi SO } \\
\text { Strategi yang } \\
\text { menggunakan kekuatan } \\
\text { dan memanfaatkan } \\
\text { peluang } \\
\text { Strategi pengembangan } \\
\text { produk }\end{array}$ & $\begin{array}{l}\text { Strategi WO } \\
\text { Strategi yang } \\
\text { meminimalkan kelemahan } \\
\text { untuk memanfaatkan } \\
\text { peluang } \\
\text { Strategi pengembangan } \\
\text { promosi }\end{array}$ \\
\hline $\begin{array}{l}\text { Threats (T)/Ancaman } \\
\text { 1. } \\
\text { 2. } \\
\text { Kurabal Warming } \\
\text { masyarakat dalam } \\
\text { melestarikan } \\
\text { lingkungan } \\
\text { 3. Kebijakan pemerintah } \\
\text { dalam pengembangan } \\
\text { pariwisata }\end{array}$ & $\begin{array}{l}\text { Strategi ST } \\
\text { Strategi yang } \\
\text { menggunakan kekuatan } \\
\text { untuk mengatasi ancaman } \\
\text { Strategi pengembangan } \\
\text { pariwisata } \\
\text { berkelanjutan }\end{array}$ & $\begin{array}{l}\text { Strategi WT } \\
\text { Strategi yang } \\
\text { meminimalkan kelemahan } \\
\text { dan menghindariancaman } \\
\text { Strategi pengembangan } \\
\text { SDM }\end{array}$ \\
\hline
\end{tabular}




\section{a. Analisis SWOT Wisata Syariah di Kampung Naga:}

\begin{tabular}{|c|c|c|}
\hline Internal / Eksternal & $\begin{array}{l}\text { Strength (S)/Kekuatan } \\
\text { 1. Seluruh } \\
\text { masyarakatnya } \\
\text { beragama Islam } \\
\text { 2. } \begin{array}{l}\text { Masjid sebagai pusat } \\
\text { kegiatan adat dan } \\
\text { agama }\end{array} \\
\text { 3. Struktur } \\
\text { pemerintahan non } \\
\text { formal ada lebe yang } \\
\text { mengurus masalah } \\
\text { keagamaan } \\
\text { 4. Tradisi lokal berbasis } \\
\text { Islam } \\
\text { 5. Arsitektur rumah, } \\
\text { masjid dan pola } \\
\text { pemukiman yang } \\
\text { unik } \\
\text { 6. Lokasi strategis dan } \\
\text { mudah diakses ada } \\
\text { lakahan parkir } \\
\text { 7. Sudah ada Tourist } \\
\text { Information Center } \\
\text { (TIC) dan pemandu } \\
\text { 8. Keindahan alam di } \\
\text { sekitar lokasi } \\
\text { 9. Sungai Ciwulan }\end{array}$ & $\begin{array}{l}\text { Weaknesses } \\
\text { (W)/Kelemahan } \\
\text { 1. } \begin{array}{l}\text { Belum maksimalnya } \\
\text { promosi }\end{array} \\
\text { 2. } \\
\text { Masih minimnya } \\
\text { fasilitas toilet untuk } \\
\text { umum yang tertutup } \\
\text { 3. } \begin{array}{l}\text { Kurang tertatanya } \\
\text { keberadaan warung }\end{array} \\
\text { dan pedagang kaki lima } \\
\text { 4. Citra Islam tradisional } \\
\text { yang masih melekat } \\
\text { kuat di masyarakat } \\
\text { sekitar } \\
\text { 5. Belum ada jadwal baku } \\
\text { mengenai kegiatan adat } \\
\text { yang bisa dipromosikan } \\
\text { 6. Sikap masyarakat yang } \\
\text { tidak mau mengekspose } \\
\text { kegiatan adat } \\
\text { 7. Sebagian masyarakat } \\
\text { belum bisa merasakan } \\
\text { dampakpositif wisata }\end{array}$ \\
\hline $\begin{array}{l}\text { Opportunities } \\
\text { (0)/Peluang } \\
\text { 1. Kondisi ekonomi global } \\
\text { 2. Kondisi ekonomi } \\
\text { nasional } \\
\text { 3. Meningkatnya minat } \\
\text { masyarakat kota dengan } \\
\text { budaya Sunda lama } \\
\text { 4. Peran serta masyarakat } \\
\text { dalam melestarikan } \\
\text { budaya } \\
\text { 5. Kondisi politik global } \\
\text { 6. Kondisi politik nasional } \\
\text { 7. Keamanan di Kabupaten } \\
\text { Tasikmalaya } \\
\text { 8. Kemajuan teknologi } \\
\text { informasi } \\
\text { 9. Kemampuan daya saing }\end{array}$ & $\begin{array}{l}\text { Strategi SO } \\
\text { Strategi yang } \\
\text { menggunakan kekuatan } \\
\text { dan memanfaatkan } \\
\text { peluang } \\
\text { Strategi pengembangan } \\
\text { produk }\end{array}$ & $\begin{array}{l}\text { Strategi WO } \\
\text { Strategi yang } \\
\text { meminimalkan kelemahan } \\
\text { untuk memanfaatkan } \\
\text { peluang } \\
\text { Strategi pengembangan } \\
\text { promosi }\end{array}$ \\
\hline
\end{tabular}




\begin{tabular}{|c|c|c|}
\hline $\begin{array}{l}\text { dengan daya tarik } \\
\text { wisata sejenis }\end{array}$ & & \\
\hline $\begin{array}{l}\text { Threats (T)/Ancaman } \\
\text { 1. Global Warming } \\
\text { 2. mulai berkurangnya } \\
\text { Kesadaran masyarakat } \\
\text { dalam melestarikan } \\
\text { lingkungan } \\
\text { 3. Kebijakan pemerintah } \\
\text { dalam pengembangan } \\
\text { wisata syariah }\end{array}$ & $\begin{array}{l}\text { Strategi ST } \\
\text { Strategi yang } \\
\text { menggunakan kekuatan } \\
\text { untuk mengatasi ancaman } \\
\text { Strategi pengembangan } \\
\text { pariwisata } \\
\text { berkelanjutan }\end{array}$ & $\begin{array}{l}\text { Strategi WT } \\
\text { Strategi yang } \\
\text { meminimalkan kelemahan } \\
\text { dan menghindari ancaman } \\
\text { Strategi pengembangan } \\
\text { SDM }\end{array}$ \\
\hline
\end{tabular}

Berdasarkan tabel ini maka terlihat adanya kekuatan dan kelemahan untuk pengembangan Wisata Syariah di Kampung Dukuh dan Kampung Naga. Di antara kekuatan (strength) dari kedua kampung ini adalah:

1) Masyarakat kedua kampung seluruhnya beragama Islam;

2) Tradisi dan budaya yang berkembang berbasis pada nilai-nilai Islam;

3) Pengunjung yang datang sebagian besar beragama Islam;

4) Kesenian yang berkembang pada kedua kampung tersebut bernafaskan budaya Islam; dan

5) Adat-istiadat yang berlaku selaras dengan nilai-nilai Islam yang universal.

Kekuatan-kekuatan tersebut menjadi dasar bagi pengembangan Wisata Syariah. Sementara kelemahan (weaknesses) dari kedua kampung ini adalah:

1) Kesadaran wisata dari masyarakatnya masih rendah;

2) Tradisi dan adat-istiadat yang berlaku masih meyakini adanya tabu atau tidak boleh melakukan sesuatu pada waktu dan tempat tertentu;

3) Pemahaman nilai-nilai syariah yang belum merata di masyarakat;

4) Kampung Dukuh hingga saat ini masih sulit untuk dijangkau, sarana transportasi yang sangat minim, dan pola pengembangan wisata yang belum dikembangkan;

5) Kebijakan pemerintah daerah yang masih kurang dalam mensosialisasikan Program Wisata Syariah;

6) Pengembangan produk wisata syariah yang belum bervariasi; dan

7) SDM yang memahami wisata syariah masih sangat terbatas. 
Kekuatan dan kelemahan yang disebutkan menjadi dasar bagi penetapan strategi pengembangan Wisata Syariah di Kampung Dukuh Garut dan Kampung Naga Tasikmalaya.

\section{Strategi Pengembangan Wisata Syariah di Kampung Dukuh dan Kampung Naga}

Berdasarkan analisis kekuatan dan kelemahan ini maka dapat dirumuskan strategi pengembangan yang bisa dilaksanakan bagi pengembangan Program Wisata Syariah sebagai berikut:

\begin{tabular}{|c|c|c|}
\hline Strategi & Strategi Pengembangan & Langkah strategis \\
\hline SO & $\begin{array}{l}\text { Strategi Pengembangan } \\
\text { Produk Wisata Syariah }\end{array}$ & $\begin{array}{l}\text { 1. Penataan Kawasan dan peningkatan } \\
\text { fasilitas pariwisata berbasis syariah Islam } \\
\text { 2. Pelaksanaan tradisi dan budaya berbasis } \\
\text { agama dan sosial bu daya lokal }\end{array}$ \\
\hline ST & $\begin{array}{l}\text { Strategi pengembangan } \\
\text { Pariwisata Berkelanjutan }\end{array}$ & $\begin{array}{l}\text { 1. Peningkatan kualitas lingkungan } \\
\text { 2. Peningkatan kualitas kehidupan } \\
\text { keagamaan dan sosial budaya masyarakat } \\
\text { Kampung Dukuh dan Kampung Naga } \\
\text { 3. Peningkatan perekonomian masyarakat } \\
\text { lokal }\end{array}$ \\
\hline Wo & $\begin{array}{l}\text { Strategi Pengembangan } \\
\text { Promosi }\end{array}$ & $\begin{array}{l}\text { 1. Promosi oleh Dinas Pariwisata Kabupaten } \\
\text { Tasikmalaya dan Garut } \\
\text { 2. Kerjasama dengan Biro Perjalanan Wisata } \\
\text { berbasis Syariah } \\
\text { 3. Pengadaan Tourist Information Center di } \\
\text { Kampung Dukuh }\end{array}$ \\
\hline WT & $\begin{array}{l}\text { Strategi Pengembangan } \\
\text { SDM }\end{array}$ & $\begin{array}{l}\text { 1. Peningkatan Sumber Daya Manusia } \\
\text { berbasis syariah } \\
\text { 2. Peningkatan pemahaman nilai-nilai Syariah } \\
\text { Islam }\end{array}$ \\
\hline
\end{tabular}

Program Pengembangan dari Strategi SO (Strengths Opportunities) adalah dengan penataan kawasan dan peningkatan fasilitas pariwisata berbasis syariah Islam. Selain itu dilakukan pula pengembangan pelaksanaan tradisi dan budaya berbasis agama dan sosial budaya lokal sebagai objek wisata syariah.

Selanjutnya program pengembangan dari strategi ST (Strengths Threats) yaitu upaya peningkatan kualitas lingkungan, Peningkatan kualitas kehidupan keagamaan dan sosial budaya masyarakat Kampung Dukuh dan Kampung Naga dan Peningkatan perekonomian masyarakat 
lokal.Adanya kegiatan wisata di wilayah mereka seharusnya dapat meningkatkan pendapat ekonomi dan kesejahteraan masyarakat di sekitarnya.

Program pengembangan dari strategi WO (Weakness Opportunities) yaitu Promosi yang lebih gencar baik oleh Dinas Pariwisata Kabupaten Tasikmalaya dan Garut ataupun Dinas kebudayaan dan Pariwisata provinsi Jawa Barat.Selain itu dijajaki kerjasama dengan Biro Perjalanan Wisata berbasis Syariah dan Pengadaan Tourist Information Center di Kampung Dukuh untuk memberikan pelayanan bagi para pengunjungnya.

Peningkatan Sumber Daya Manusia berbasis Syariah dilakukan dengan peningkatan sumber daya manusia (SDM) berbasis syariah serta peningkatan pemahaman nilai-nilai Syariah Islam. Upaya ini dapat dilakukan dengan cara membuat pelatihan, workshop dan pendalaman terhadap materi-materi keislama secara berkesinambungan kepada para pemandu wisata pada khususnya dan warga masyarakat pada umumnya.

\section{E. Penutup}

Kampung Dukuh dan Kampung Naga adalah dua kampung adat yang ditempati oleh komunitas adat yang hingga saat ini masih memegang teguh keyakinan agama dan kepercayaannya.Mereka memiliki berbagai tradisi dalam bentuk upacara keagamaan dan ritual yang dilakukan secara berkala, selain itu arsitektur rumah dan bangunan serta pola pemukiman mereka adalah inti dari destinasi wisata yang dijual selama ini.Strategi pengembangan wisata syariah ditetapkan dengan melihat pertimbangan kekuatan dan kelemahan yang ada pada kedua lokasi penelitian.

Kekuatan (strength) yang ada pada Kampung Dukuh meliputi kondisi keagamaan masyarakatnya yang seluruhnya adalah muslim, tradisi mereka didasarkan pada nilai-nilai Islam dan kondisi lingkungan yang mendukung bagi pelaksanaan wisata berbasis syariah. Sementara kelemahan Kampung Dukuh adalah lokasinya yang jauh berada di pedalaman sehingga akses menuju lokasi sulit dan kondisi jalannya rusak. Sementara kampung ini belum dioptimalkan sebagai objek wisata sehingga sarana-sarana pendukunya seperti touris information centre belum ada. Demikian pula pelayanan berupa pemandu wisata belum diadakan oleh masyarakat dan tetua kampung. 
Kekuatan (strength) pada Kampung Naga adalah aristektur rumah dan pola pemukimannya yang telah dikenal oleh dunia, sementara penduduknya seluruhnya adalah muslim yang melaksanakan adatistiadat yang selaras dengan nilai-nilai syariah Islam. Lokasinya yang mudah diakses serta tradisi dan adat-istiadatnya sangat banyak dan dilakukan secara berkala menjadikan Kampung Naga menjadi tempat yang banyak dikunjungi oleh masyarakat dalam dan luar negeri. Kelemahannya adalah belum optimalnya promosi oleh dinas terkait terutama berkaitan dengan Program Wisata Syariah.

Strategi pengembangan yang bisa dilakukan untuk pengembangan Program Wisata Syariah adalah strategi pengembangan produk wisata berbasis syariah, strategi pengembangan wisata berkelanjutan, strategi pengembangan promosi dan pengembangan sumber daya manusia (SDM) berbasis pada nilai-nilai Islam.

\section{DAFTAR PUSTAKA}

Amirullah. 2004. Manajemen Strategik. Yogyakarta: Graha Ilmu.

Anonimous. 2012. Panduan Wisata Syariah. Jakarta: Kementerian Pariwisata dan Ekonomi Kreatif Republik Indonesia.

Cooper, C. And Jackson, S. L. 1997. Destination Life Cycle: The Isle of The man Case Study. (ed. Lesly, France) dalam The Earthscan Reader in Sustainable Tourism. UK: Earthscan Publication Limited.

Haq, F. dan Jackson, J. 2006. Exploring Consumer Segments and Typologies of Relevance to Spiritual Tourism. Queensland: Central Queensland University.

Harun, Ismet Belgawan dkk. 2011. Arsitektur Rumah dan Permukiman Tradisional di Jawa Barat.Hasil Pengamatan dan Dokumentasi. Bandung: Dinas Pariwisata dan Kebudayaan Provinsi Jawa Barat.

http://bps.go.id/download_file/Penduduk_Indonesia_menurut_desa_SP 2010.pdf.

http://www.budpar.go.id/asp/detil.asp?c=16\&id=2042.

http://www.itc.gov.my/content.cfm. 
Koentjaraningrat. 1981. Pengantar Ilmu Antropologi. Jakarta: Rineka Cipta.

Kusmayadi dan Sugiarto, E. 2000. Metodologi Penelitian dalam Bidang Kepariwisataan. Jakarta: PT Gramedia Pustaka Utama.

Marpaung, H. 2002. Pengetahuan Kepariwisataan. Bandung: Alfabeta.

McIntosh, Robert W dan Goeldner, Charles R. 1986. Tourism Principle, Practices and Philosophies. New York: L John Wiley \& Sons.

Misno. 2014. "Penyerapan Hukum Islam Pada Komunitas Adat: Studi Antropologi di Baduy, Kampung Naga dan Marunda Pulo" dalam Disertasi UIN Sunan Gunung Djati.

Moleong, Lexy, J. 2002. Metodologi Penelitian Kualitatif. Bandung: Remaja Rosda Karya.

Nazir, Moh. 1999. Metode Penelitian. Jakarta: Ghalia Indonesia.

Poerwadarminton. 2002. Kamus Umum Bahasa Indonesia. Jakarta: Balai Pustaka.

Rangkuti, F. 2005. Analisis SWOT, Teknik Membedah Kasus Bisnis. Jakarta: PT. Gramedia Pustaka Utama.

Rostiyati, Ani dkk. 2004. Potensi Wisata Di Daerah Pameungpeuk Kabupaten Garut. Bandung: Balai Pelestarian Sejarah dan Nilai Tradisional Bandung.

Suganda, Her. 2005. Kampung Naga Mempertahankan Tradisi. Bandung: PT. Kiblat Buku Utama.

Suryani, Elis dan Charliyan, Anton. 2010. Menguak Tabir Kampung Naga, Tasikmalaya: Danan Jaya.

Tarigan, R. 2005. Perencanaan Pembangunan Wilayah. Jakarta: PT. Bumi Aksara.

Undang-Undang Republik Indonesia Nomor 10 tahun 2009 tentang Kepariwisataan.

Wihardi, Didik dkk. "Sistem Konversi Hak atas Tanah Adat Kampung Naga". dalam Jurnal Sosioteknologi Edisi 20 Tahun 9, Agustus 2010. 
200 | 'Adliya Vol. 10, No. 2, Juni 2016

Yoeti, O. A. 2006. Pariwisata Budaya Masalah dan Solusinya. Jakarta: PT.. Pradnya Paramita.

Wawancara dengan Ketua Adat Kampung Dukuh Mama Uluk.

Wawancara dengan Kuncen Kampung Naga Bpk. Ade Suherlin.

Wawancara dengan Kang Yayan warga Kampung Dukuh.

Wawancara dengan Bpk. Sholaha warga Kampung Dukuh.

Wawancara dengan Kang Entang Warga Kampung Naga.

Wawancara dengan Punduh Maun Sesepuh Kampung Naga. 